\title{
THE ECONOMIC AND SOCIAL CONSEQUENCES OF THE INCREASE IN THE NUMBER OF EMPLOYEES WORKING, AS AN EFFECT OF THE CORONAVIRUS PANDEMIC, IN THE TELEWORK REGIME IN ROMANIA*
}

\author{
Dan TुOP**
}

\begin{abstract}
The coronavirus pandemic accelerated the transition to online by 5 years. Although the IT industry has exploded in the last 20 years, Romania is still at the bottom of the European ranking on digitization, ranking 26th out of 28 countries. In Romania only in 2020 the Romanian Digitization Authority (ADR) was established. and a ministry of research and digitization has been set up and some interesting provisions appear in the government program, such as the introduction of informatics in primary classes. Statistics show that only 9.2 percent of jobs with earnings below the average wage in the economy could be done in telework. It is now more difficult to assume that there will ever be a return to normalcy, especially since the restrictive measures imposed over a longer period of time lead to changes in human behavior in such a way that it is impossible to predict to what extent once. what the crisis generated by Covid-19 will disappear will return to a lifestyle similar to that before this period.

Keywords: coronavirus pandemic; telework; digitization
\end{abstract}

DOI: 10.53373/ REDS.2021.52.3.021

ID 0000-0002-1695-9967

On March 11, 2020, representatives of the World Health Organization declared $^{1}$ the situation generated by COVID-19 as a pandemic ${ }^{2}$. At the same time, the National Committee for Special Emergency Situations in Romania decided to suspend the school courses until March 22, with the

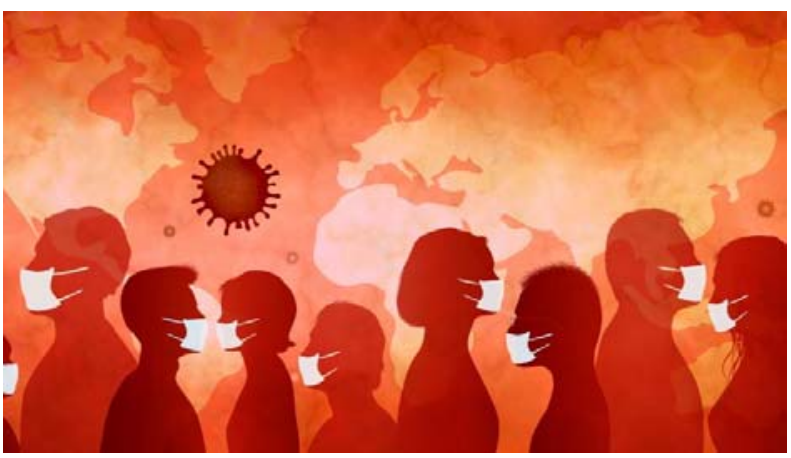

\footnotetext{
* Paper presented at the International Conference "The future of labor law after coronavirus" organized on-line by the Association for the Study of Professional Labor Relations on May 13 and 14, 2021.

** $\mathrm{PhD}$ professor, Valahia University of Târgovişte.

${ }^{1}$ www.who.int, accessed march 12, 2020

${ }^{2}$ An epidemic that extends over a very large territory
} 
possibility of extension. Separately, the universities in the country suspended their activity until March 31 and moved the courses into the online system ${ }^{3}$.

The pandemic has had a negative impact on labor relations since March 2020 and even if at first glance it seems that the total number of employees has not changed considerably, looking closely at the type of individual employment contracts we find that we are facing a change of employment. perspective leading to precariousness ${ }^{4}$.

\begin{tabular}{|c|c|c|c|c|c|c|c|c|c|c|c|}
\hline \multirow{3}{*}{\begin{tabular}{|l|} 
Data de referinţă \\
31.01 .2020 \\
\end{tabular}} & \multirow{2}{*}{\multicolumn{2}{|c|}{ Numar salariati activi }} & \multicolumn{9}{|c|}{ Numar de contracte } \\
\hline & & & \multicolumn{2}{|r|}{ Total } & \multicolumn{2}{|c|}{ Nedeterminata } & \multicolumn{2}{|c|}{ Determinata } & \multicolumn{2}{|c|}{ Norma intreaga } & Timp partial \\
\hline & $\mathbb{4}$ & 5.705 .252 & 27 & 6.461 .993 & $y$ & 5.951 .719 & 2ี & 510.274 & $\hat{\mathrm{T}}$ & 5.531 .373 & $\Downarrow \quad 930.620$ \\
\hline 29.02 .2020 & A & 5.750 .786 & $\mathrm{~A}$ & 6.523 .549 & 个 & 5.996 .615 & 会 & 526.934 & $\hat{\imath}$ & 5.563 .845 & $\Downarrow \quad 959.704$ \\
\hline 31.03 .2020 & $\hat{\mathrm{A}}$ & 5.733 .839 & $\uparrow$ & 6.501 .001 & วิ & 5.969 .646 & 个 & 531.355 & $y$ & 5.434 .601 & م 1.066 .400 \\
\hline 30.04 .2020 & $\downarrow$ & 5.693 .070 & 2 & 6.452 .091 & $\downarrow$ & 5.928 .955 & $\hat{\mathrm{T}}$ & 523.136 & $\psi$ & 5.364 .271 & 个 1.087 .820 \\
\hline 31.05 .2020 & $\downarrow$ & 5.679 .085 & 4 & 6.434 .327 & $\downarrow$ & 5.918 .424 & 2. & 515.903 & $\downarrow$ & 5.369 .463 & 个 1.064 .864 \\
\hline 30.06 .2020 & $\downarrow$ & 5.680 .934 & $\psi$ & 6.373 .188 & $\downarrow$ & 5.922 .111 & $\downarrow$ & 451.077 & $\downarrow$ & 5.389 .541 & 인 983.647 \\
\hline 31.07 .2020 & M & 5.699 .306 & $\downarrow$ & 6.380 .307 & $\downarrow$ & 5.931 .512 & $\downarrow$ & 448.795 & $\downarrow$ & 5.412 .610 & $\begin{array}{ll}\Downarrow & 967.697 \\
\end{array}$ \\
\hline 31.08 .2020 & 4 & 5.690 .794 & $\downarrow$ & 6.352 .893 & $\downarrow$ & 5.929 .409 & 4 & 423.484 & $\downarrow$ & 5.402 .689 & $\Downarrow \quad 950.204$ \\
\hline 30.09 .2020 & 4 & 5.700 .191 & $M$ & 6.412 .526 & $\downarrow$ & 5.927 .832 & 난 & 484.694 & $\psi$ & 5.406 .140 & 1.006.386 \\
\hline 31.10 .2020 & 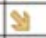 & 5.714 .536 & 27 & 6.466 .101 & $\downarrow$ & 5.932 .949 & $\uparrow$ & 533.152 & $\downarrow$ & 5.401 .497 & 个 1.064 .604 \\
\hline 30.11 .2020 & \% & 5.741 .506 & 个 & 6.506 .930 & $y$ & 5.952 .094 & ค & 554.836 & $\downarrow$ & 5.410 .882 & 个 1.096 .048 \\
\hline 28.12 .2020 & $y$ & 5.710 .313 & ริ & 6.477 .578 & $\downarrow$ & 5.934 .396 & $\hat{\imath}$ & 543.182 & $\downarrow$ & 5.381 .458 & 个 1.096 .120 \\
\hline
\end{tabular}

According to the data provided by the Labor Inspectorate ${ }^{5}$, at the end of 2020 we have fewer open-ended and full-time employment contracts, but also with almost 40,000 fewer active employees than in March 2020.

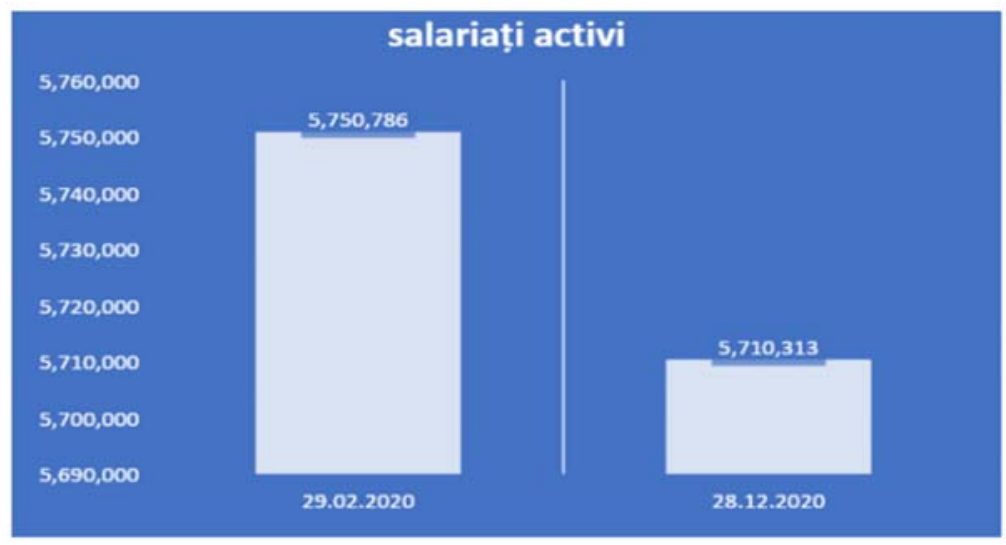

In February 2020, before the declaration of the state of emergency ${ }^{6}$ on the Romanian territory, at national level there were 5,750,786 employees and 6,523,549 employment contracts, distributed as follows:

${ }^{3}$ Dan Top, Overview and perspectives of labor law against the coronavirus pandemic (Covid-19): Romania, in Noticias CIELO nr. 4/2020, www,cielolaboral.com

${ }^{4}$ Dan Năstase, Cum au evoluat relațiile de muncă în 2020, www.avovatnet.ro, 7 ianuarie 2021

${ }^{5}$ www.inspectiamuncii.ro

${ }^{6}$ The state of emergency was established in Romania on March 16, 2020 by Decree no. 195/2020 and extended until May 14, 2020 by Decree no. 240/2020 
- 5,996,615 - determined period;

- 526,934 - determined period;

- 5,563,845 - full time;

- 959,704 - part-time.
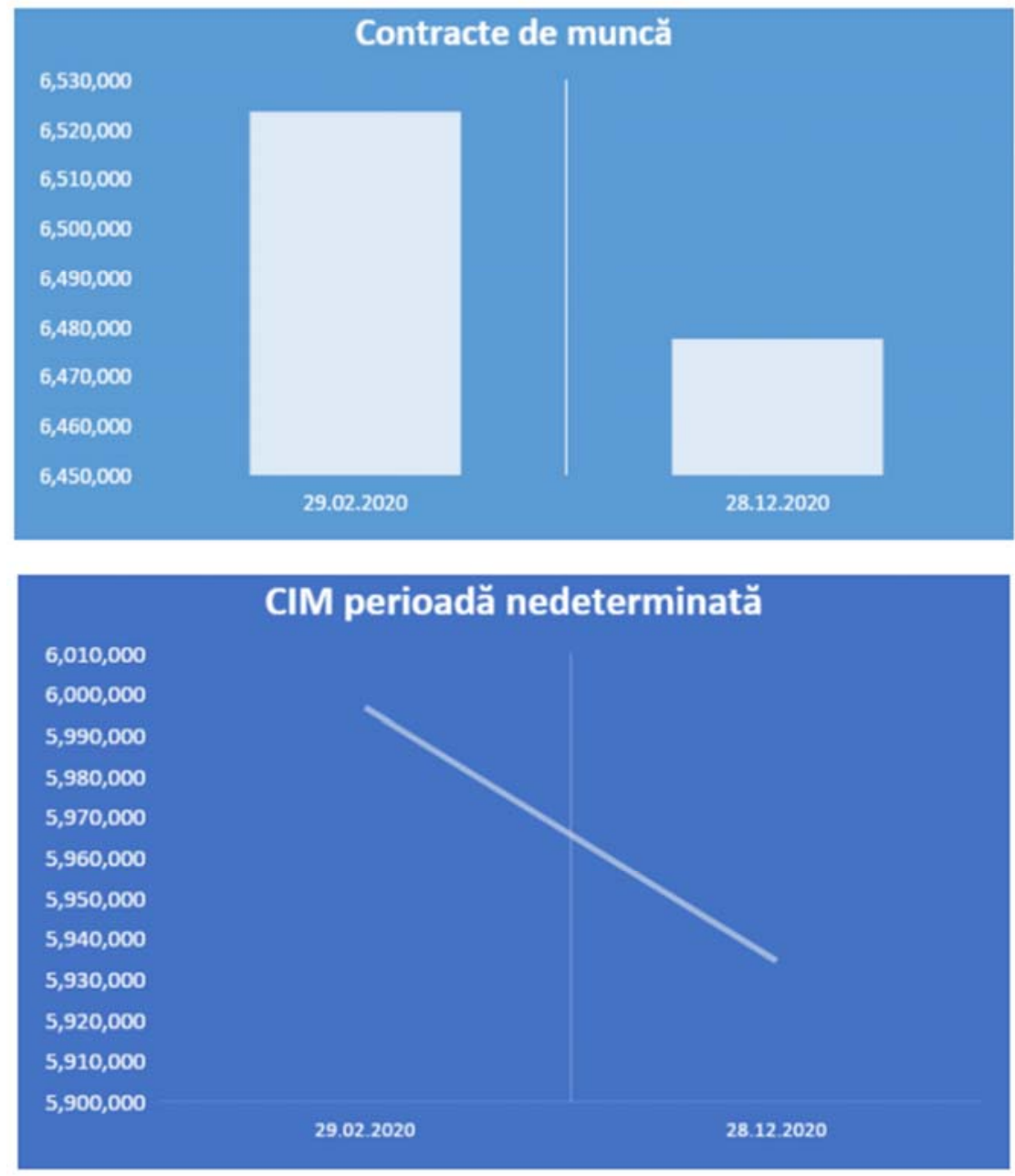

At the beginning of the pandemic, there were 772,763 employment contracts in addition to the total number of employees, and this number represents employees who have at least two employment contracts, concluded with another employer or with the same one, according to art. 35 paragraph (1) of the Labor Code ${ }^{7}$. At the end

${ }^{7}$ Law no. 53 of February 5, 2003 - Labor Code, republished in the Official Gazette of Romania, Part I, no. 345 of May 18, 2011 
of December 2020, the number of those with at least two employment contracts decreased to 767,265 , the difference not being significant $(5,498)$.

We cannot say the same regarding the change in the number of employment contracts concluded for a certain period, which is 16,248 higher compared to the one registered at the beginning of March 2020.

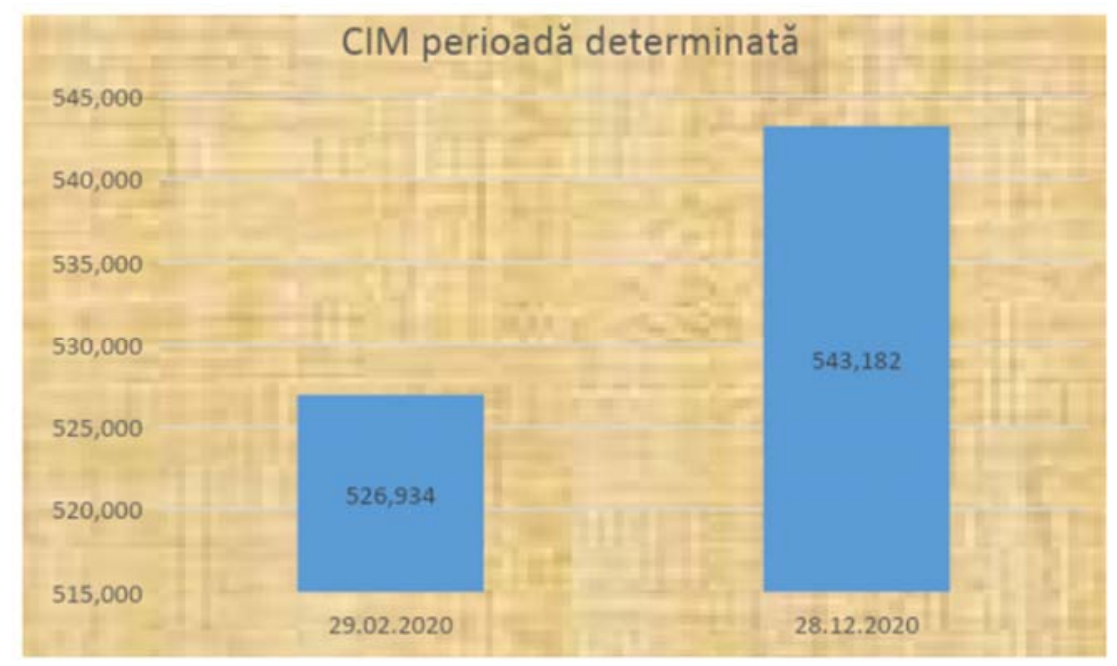

At the same time, the number of individual part-time employment contracts increased, currently being 1,096,120, from 959,704 in February 2020.

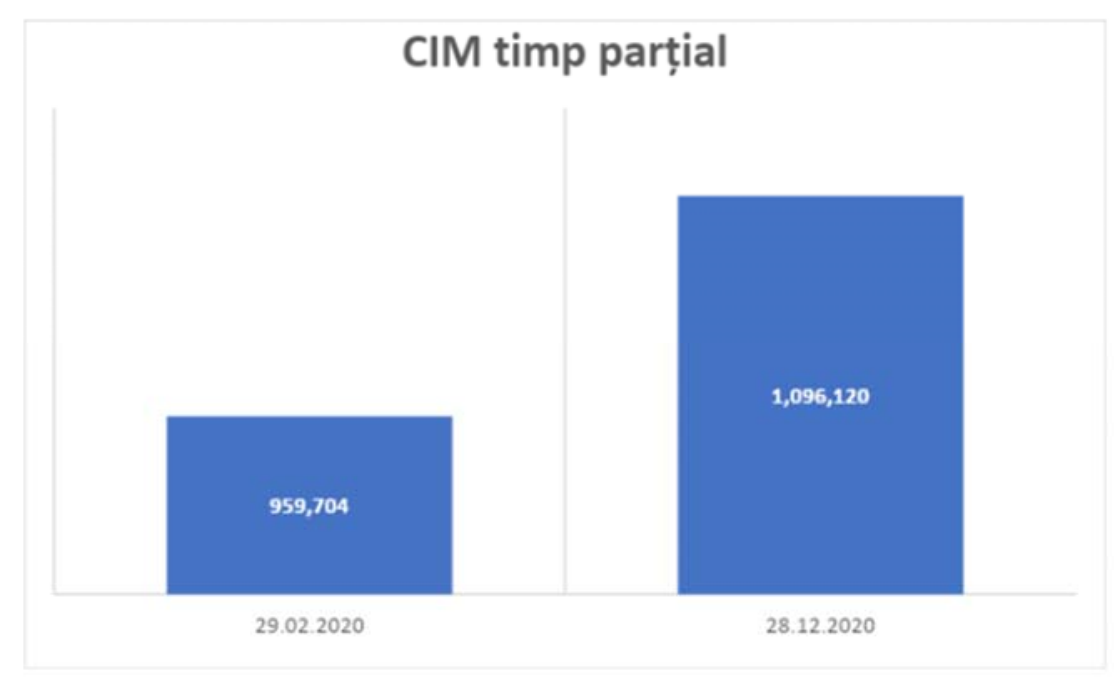


It can be assumed that a large part of these part-time employment contracts belongs to employees who combine two or more employment contracts, but in the absence of sufficiently clear data, the difference of 136,414 part-time employment contracts can be attributed to some employees who have a single employment relationship, and that is not full-time.

All these data lead to the conclusion that, although we do not have a very big difference in the number of employment contracts and active employees, we have an increase in employment relationships for a fixed period and part-time.

In Romania, the implementation of the Kurzarbeit model involves the subsidy by the Government of a part of the salaries for those workers whose employers have changed their working hours from normal to part-time, due to the economic crisis. The state thus grants the value of labor for the days when they are no longer called to work by employers ${ }^{8}$.

Government Emergency Ordinance no. 92/2020 for the establishment of active support measures for employees and employers in the context of the epidemiological situation caused by the spread of SARS-CoV-2 coronavirus, as well as for the amendment of some normative acts, provides that from 1 June 2020, employers whose employees benefited from the provisions of the Government Emergency Ordinance no. 30/2020 for amending and supplementing some normative acts, as well as for establishing measures in the field of social protection in the context of the epidemiological situation caused by the spread of SARS-CoV-2 coronavirus, benefits, for a period of three months, from the settlement of part of the salary, borne by the unemployment insurance budget, representing $41.5 \%$ of the gross basic salary corresponding to the job held, but not more than $41.5 \%$ of the average gross earnings

The measure applies for a limited period, when a major market disturbance occurs, such as the economic crisis caused by the COVID epidemic. So, we will have to set a period of application and we will have to think very carefully about how we put this mechanism in place, so that on the one hand it is as easy to access as possible, without complicated bureaucratic procedures. On the other hand, to provide very clear, very precise criteria for granting aid to companies and employees, so that there are no major problems in interpreting how it is applied and to reduce as much as possible the possibility that some employers may to use this form of protection without the need or as an additional resource of income, provided that they, in theory, would not need this measure.

The Kurzarbeit model is something that a business environment that faces zero predictability, not through no fault of its own, needs. Unlike other fixed economic aid measures that apply to everyone, this model is a flexible measure that is applied individually per company, department, per employee and per day, which offers additional benefits.

\footnotetext{
${ }^{8}$ Dan Top, Flexibilization of labor relations in Romania - Kurzarbeit model, Noticias CIELO, no. 6/2020, www,cielolaboral.com
} 


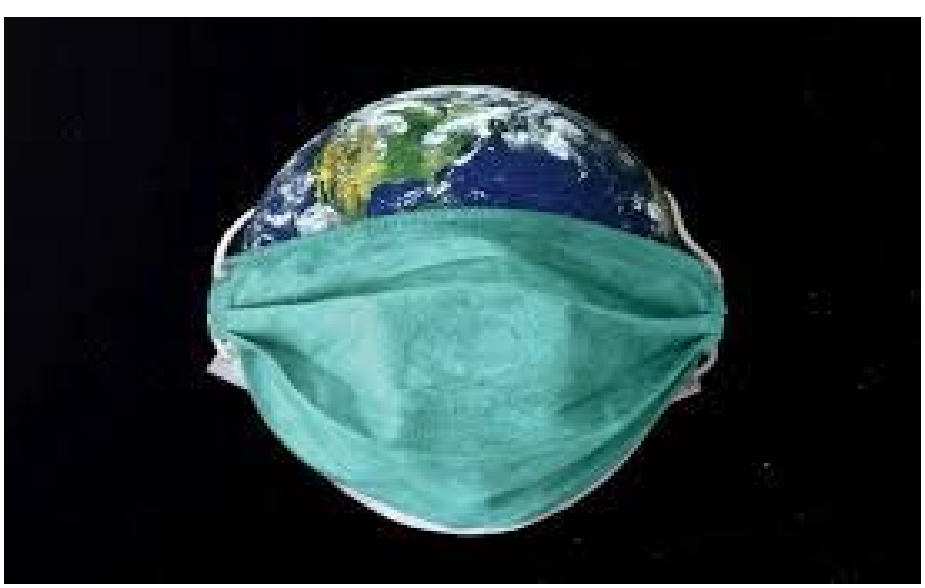

The coronavirus pandemic accelerated the transition to online by 5 years. However, 2 out of 3 Romanians are digitally illiterate.

The world of work is undergoing major changes that will continue, and tally intensify, in the future. The employment relationship as we currently understand he product of a historical, evolutionary process. The current context is characterized new nature and structure of work that has changed the previous forms of production. employment relationship continues to be under pressure. The reality of the employment on ship, and especially its use as a means to determine the allocation of rights and protections to workers, varies. Many workers in an employment relationship do not enjoy protection, and many workers are unable to secure work within an employment relationship. Both types of exclusions will continue in the future in the absence of live policy action. The standard employment relationship is being eroded in many tries, with more workers finding themselves outside the employment relationship itself. There is a need to act at global level for enforcing the basic principles and rights at work in any local context. ${ }^{9}$

If only $0.6 \%$ of all employees in Romania worked sporadically from home in 2019, the share rose in 2020 to $24 \%$ of employees who worked exclusively from home $^{10}$. The evolution of telework in Romania has been insignificant in the last decade - a country that occupied every year the last position of the EU ranking, achieved according to the percentage of total workers, and rose from $0.1 \%$ of employees who worked from time to time from home, at only $0.6 \%$, in 2019 .

This year, the share jumped to $24 \%$ of the total, employees who work and work only remotely, which propelled Romania six positions in the EU27 ranking

\footnotetext{
${ }^{9}$ Giuseppe Casate, The future of work and the employment relationship, în volumul Hic et Nunc: Alexandru Athanasiu, editura CHBeck, Bucureşti, 2020, p.247

${ }^{10}$ Working conditions in sectors, www.eurofound.europa.eu
} 
Although the IT industry has exploded in the last 20 years, Romania is still at the bottom of the European ranking on digitization ${ }^{11}$. ranking 26th out of 28 countries, surpassing only Bulgaria and Greece.
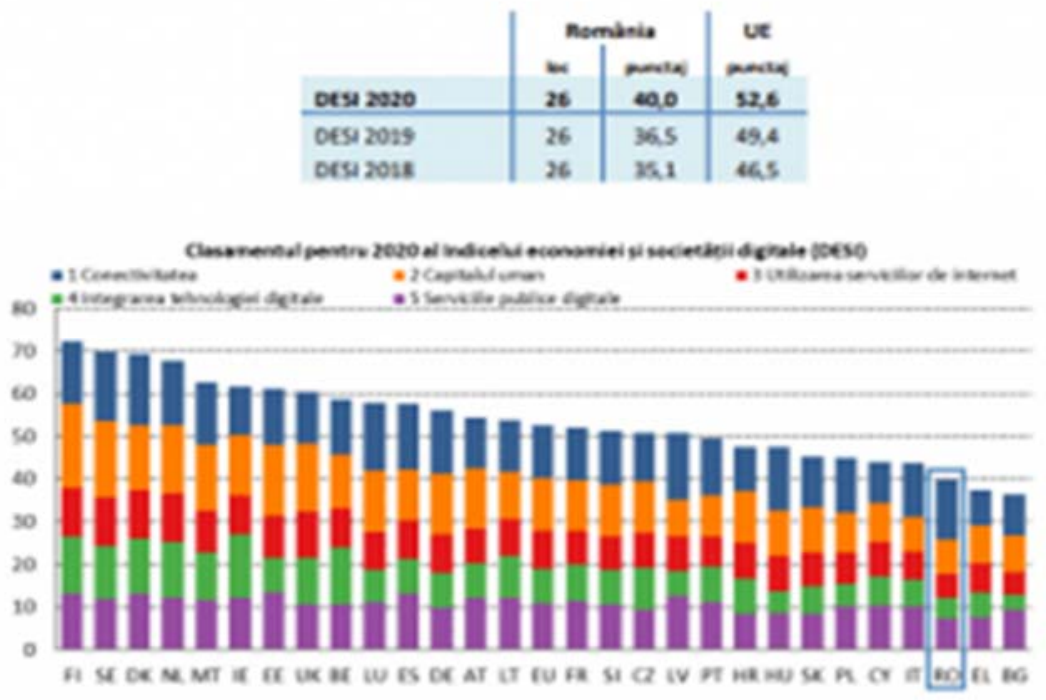

Statistics show that only 9.2 percent of jobs with earnings below the average wage in the economy could be done in telework. Thus, it cannot be neglected that there will be effects in terms of income earned by the population, this effect can be seen mutatis mutandis even in the case of Romania, given that the development of teleworking activity involves the loss of bonuses for employees, not excluding the loss of other benefits that make up the monthly salary and whose elimination will lead to its decrease ${ }^{12}$.

Only $1.3 \%$ of Romanian adults were actively involved in a learning program, traditional or digital. We are moving towards a learning model that we see as viable even after the pandemic, and which is suitable for employees, students and high school students. It is a mix of face-to-face education, synchronous webinars and selfpaced learning by accessing digital resources. The latter mode is accessible anytime, from anywhere and with any device that has an internet browser.

Although on paper Romania should invest 6\% of GDP in Education, in reality, over the years The education system has benefited from a maximum of $3 \%$ of GDP.

\footnotetext{
${ }^{11}$ Ana-Maria Masoud, Deși industria IT a explodat în ultimii 20 de ani și ne place să ne numim un „Silicon Valley al Europei”, România este în continuare la coada clasamentului european privind digitalizarea, www.project-e.ro. accesat la data de 24 ianuarie 2021

${ }^{12}$ Ana-Maria Crînguș-Echert Unele consecințe ale pandemiei generate de virusul sars-cov-2 asupra dreptului de proprietate, în Dreptul nr. 3/2021, p. 16
} 
And in this chapter, as in digitalization, Romania is at the bottom of the ranking in the European Union.

Government spending on education in the European Union in 2017:
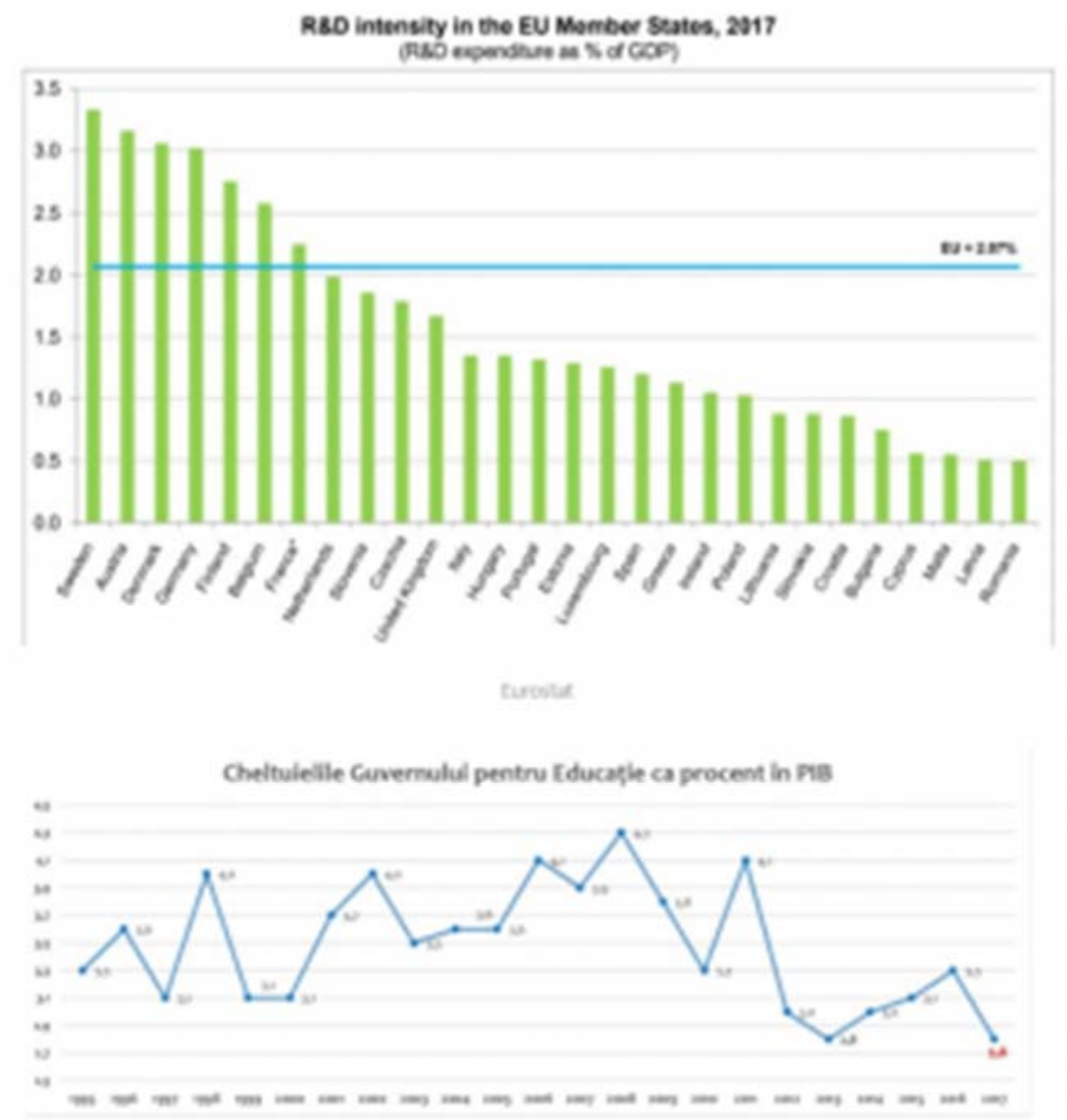

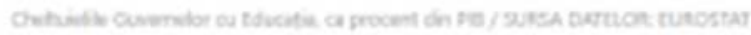

Unfortunately, never in the 30 years since the Revolution, Romania has not invested in education, and we see the results today (the lowest score on the PISA and TIMSS tests, the very high percentage of functionally illiterates that the Romanian school produces) and we will see them even better in the next 20 years.

Romanian education seems frozen in time, in the curriculum there are no essential subjects for the world we live in: for example, robotics, computer science in small classes, STEM; we memorize comments in an age where memory no longer 
plays such an important role, information being very accessible, we do not develop critical thinking, public speaking skills, digital skills, creativity and imagination.

In addition to the above, we also face an acute shortage of teachers with adequate training, education no longer being an attractive career for young people today. And it seems that some teachers, in 2021, are more interested in numerology courses than digitization, which is really worrying.

Estonia, the benchmark country in the field, started investing in digital since 1994 when the government signed the first political act for digitization and in 1999 the first online service appeared, while in Romania only in 2020 the Romanian Digitization Authority (ADR) was established. and a ministry of research and digitization has been set up and some interesting provisions appear in the government program, such as the introduction of informatics in primary classes.

The restrictions imposed in most European countries are economically devastating. As many businesses are closed and almost everyone is limited to their own homes, economic activity has fallen dramatically. Many companies have gone bankrupt, unemployment has accelerated, and household incomes are falling ${ }^{13}$.

In Romania, before March 2020, the use of digital learning in companies was below $1 \%$ and it would be necessary that employers implement programs for team development in organizations, thus compensating for skills that the school fails to develop.

Developing the career of our employees is an investment both for them and for the future of our company. Reimbursement of schooling, on-site training courses to improve their skills and access to conferences and seminars, emerging leadership programs for training and professional development, or exchange of experience programs are some of the best benefits an employee can enjoy.

This crisis is clearly distinguishable from any other in history regardless of its type... In order to prevent the spread of the new virus, given that it had impact, the vast majority of states have taken unprecedented measures in history, both in terms of impact and duration, having to identify a legislative context. allowing for deep interference with fundamental rights and freedoms, with the stated aim of limiting the impact of the Covid-19 pandemic and too much pressure on the health system ${ }^{14}$.

Regarding the current context, it has been shown ${ }^{15}$ that "There is no such serious precedent, and this will make it difficult to correctly assess future developments in national and global economic terms".

\footnotetext{
${ }^{13}$ Gh. Zaman, A. Cristea (coordonatori), V. Vasile, Z. Goschin, M. Surugiu, R. Mazilescu, O. ChindrișVasioiu, C. Dumitru, M. Tocan, Rolul statului-națiune în gestionarea crizei SARS-CoV-2 din România. Politici de combatere, recuperare și reziliență în domeniul economiei, Academia Română, Secția de Științe Economice, Juridice și Sociologie, Institutul de Economie Națională, p. 21, disponibil pe https://acad.ro/, consultat la 11 octombrie 2020.

${ }^{14}$ Ana-Maria Crînguș-Echert, Unele consecințe ale pandemiei generate de virusul SARS-CoV-2 asupra dreptului de proprietate, Dreptul nr. 3/2021, p. 13-14

${ }^{15}$ N. Pop, V. loan-Franc, A. M. Diamescu, Resetarea ordinii economice mondiale. Pandemia - noua față întunecată a globalizării, Academia Română. Secția de Științe Economice, Juridice și Sociologie. Institutul Național de Cercetări Economice „Costin C. Kirițescu”, Faza I - aprilie/mai 2020, România postpandemie - viziunea 2040 - și destinul viitoarei Uniuni Europene, București, mai 2020, p. 22, available on https://acad.ro/, consulted on October 11, 2020.
} 
It is obvious that COVID-19 infection is of occupational origin and should be recognized as occupational disease ${ }^{16}$, not only in terms of providing incentives or facilitating the involvement of medical staff, but especially for medical staff who died in this terrible situation with a unique pandemic.

It is now more difficult to assume that there will ever be a return to normalcy, especially since the restrictive measures imposed over a longer period of time lead to changes in human behavior in such a way that it is impossible to predict to what extent once. what the crisis generated by Covid-19 will disappear will return to a lifestyle similar to that before this period.

\footnotetext{
${ }^{16}$ Dan Top, The need to include coronavirus Covid-19 infection in the category of occupational disease în Legal Responses to Covid-19 around the World, Claudio Janotti, Flávia Fragale M. Pepino, Rafael Lara Martins (coordinators), editura Lex Magister, Porto Alegre, 2020, p.400
} 